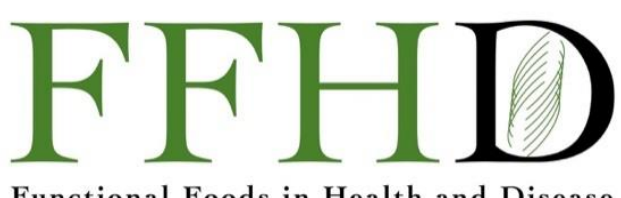

Functional Foods in Health and Disease

\title{
The green tea polyphenol EGCG is differentially associated with telomeric regulation in normal human fibroblasts versus cancer cells
}

\author{
Angelika Pointner ${ }^{1}$, Christine Mölzer ${ }^{1,2}$, Ulrich Magnet ${ }^{1}$, Katja Zappe ${ }^{1,3}$, Berit Hippe ${ }^{1}$, Anela \\ Tosevska ${ }^{1,4}$, Elena Tomeva ${ }^{1}$, Elisabeth Dum ${ }^{1}$, Stephanie Lilja ${ }^{1}$, Ulrike Krammer ${ }^{1}$, Alexander \\ Haslberger $^{1^{*}}$
}

\begin{abstract}
${ }^{1}$ Faculty of Life Sciences, Department of Nutritional Sciences, University of Vienna, Vienna, Austria; ${ }^{2}$ University of Aberdeen, School of Medicine, Medical Sciences and Nutrition, Institute of Medical Sciences, Foresterhill, Aberdeen, United Kingdom; ${ }^{3}$ Department of Analytical Chemistry, Faculty of Chemistry, University of Vienna, Vienna, Austria; ${ }^{4}$ Department of Molecular, Cell, and Developmental Biology (MCDB), University of California, Los Angeles, CA, United States of America
\end{abstract}

*Corresponding author: Alexander Haslberger, Faculty of Life Sciences, Department of Nutritional Sciences, University of Vienna, Vienna, Austria

Submission Date: January $7^{\text {th }}, 2021$; Acceptance Date: March 1 ${ }^{\text {st }}, 2021$; Publication Date: March $9^{\text {th }}, 2021$

Please cite this article as: Pointner A., Molzer C., Magnet U. Zappe K., Hippe B., Tosevska A., Haslberger A. The green tea polyphenol EGCG is differentially associated with telomeric regulation in normal human fibroblasts versus cancer cells. Functional Foods in Health and Disease 2021. 11(3): 73-91. DOI: https://www.doi.org/10.31989/ffhd.v11i3.775

\footnotetext{
ABSTRACT

Introduction: Topical investigations have demonstrated that oxidative stress and inflammation play key roles in biological aging and determine incidence and course of age-related diseases. Lifestyle and environmental factors hugely impact epigenetic regulation and DNA stability with telomere attrition and epigenetic instability providing a potential record of the cumulative burden of endogenous and exogenous oxidative noxae. Certain physiologically active plant components exhibit antioxidative activities affecting epigenetic regulation of inflammation response and DNA repair.
}

Methods: Against this background, the present study investigated green tea polyphenol epigallocatechin gallate (EGCG) in the context of telomere regulation in Caco-2 colorectal adenocarcinoma cells vs. ES-1 primary skin fibroblasts. Cell lines were treated with 20 and $200 \mu \mathrm{M}$ EGCG for 36, 72 and 144 hours, respectively. Telomerase 
activity, relative telomere length as well as methylation status of $h T E R T$ and $c-M y c$ from different culture conditions were assessed. Malondialdehyde (MDA) served as a surrogate marker of potential prooxidative effects of EGCG in a physiologically relevant tissue model.

Results: EGCG incubation was associated with telomere shortening and decreased telomerase activity in Caco-2 cells, and relatively longer telomeres along with increased methylation of six $5^{\prime}-\mathrm{C}-$ phosphate- $\mathrm{G}-3^{\prime}(\mathrm{CpG})$ sites in the promoter region of human Telomerase Reverse Transcriptase (hTERT) in fibroblasts. At low concentrations, EGCG significantly decreased oxidative damage to lipids in Caco- 2 cells and attenuated $\mathrm{H}_{2} \mathrm{O}_{2}$ induced oxidation at higher concentrations.

Conclusion: These results suggest differential EGCG-

\section{PRIMARY CELLS CANCER CELLS ES-1 Caco-2}

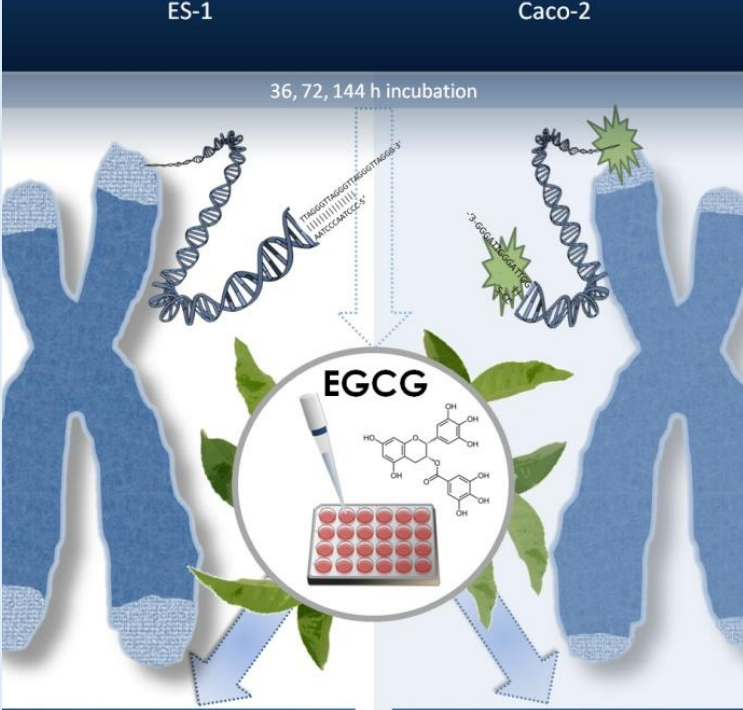

Telomere length

Telomerase activity $\mathbf{Q}$

Telomere length

Telomerase activity

hTERT methylation $c-M y c$ methylation
$\Leftrightarrow$ hTERT methylation

- $c-M y c$ methylation mediated telomeric modulation in cancer vs. primary cells and a specific antioxidant activity of EGCG against oxidative damage to lipids in abnormal cells.

Keywords: Caco-2, epigallocatechin gallate, telomeres, hTERT, DNA methylation, telomerase, oxidative stress, malondialdehyde

CFFC 2021. This is an Open Access article distributed under the terms of the Creative Commons Attribution 4.0 License (http://creativecommons.org/licenses/by/4.0)"

\section{INTRODUCTION}

Over the past decades, redox research has demonstrated key roles for oxidative stress and inflammation in biological aging and associated diseases. Today it is commonly accepted that lifestyle and environmental factors hugely impact epigenetic regulation and DNA stability through telomere attrition. Further, epigenetic instability provides a potential record of the cumulative burden of those endogenous and exogenous oxidative stressors encountered over time $[1,2,3]$. Redox homeostasis is essential for regulating cell growth, senescence and aging, and antioxidants are key players in maintaining an appropriate threshold cellular redox state [4]. Hence, unsurprisingly, an overt increase in reactive oxygen species (ROS) is associated with oxidative stress in the intracellular redox system, damage to macromolecules such as lipids, proteins and DNA, and has been linked to several diseases including neurodegenerative disorders $[5,6]$. Due to increased metabolic demand, ROS producing processes are typically upregulated in cancer. Concurrently, 
quantitative and qualitative changes in metabolic pathways and cell cycle control result in hyperproliferation, aggravating DNA damage, inflammation and genomic instability [7].

Cell culture studies have repeatedly shown oxidative stress levels dose-dependently accelerate telomeric attrition [8,9]. Human telomeres are comprised of tandem repeats of a hexameric nucleotide sequence (TTAGGG) that is associated with the shelterin group of proteins. The telomere protein complex is crucial for genomic stability and chromosomal integrity hence why telomere length has been suggested as a biomarker of biological aging [10]. Conversely, telomeric dysfunction and accelerated attrition have been linked to age-related conditions like cancer, cardiovascular disease, type 2 diabetes and neurodegeneration [11,12]. With its specialized ribonucleoprotein structure, the enzyme telomerase is a critical determinant of telomere length as it synthesizes telomeric repeat DNA, consequently slowing down telomere attrition. Human telomerase contains two core components, a catalytic unit called the human telomerase reverse transcriptase (hTERT) and an RNA template (hTERC), along with associated proteins. In adults, most healthy somatic cells express very low telomerase activity in contrast to cells with high replicative demands including fetal epithelial cells, and cells of the immune system [13]. Telomerase enzyme activity is regulated by an intricate multi-stage control machinery including transcriptional, posttranscriptional and post-translational mechanisms with the transcriptional regulation of human $h T E R T$ representing a major rate limiting factor. The $h T E R T$ gene is located in chromosome $5 p 15.33$ [14]. The hTERT core promoter forms three parallel G- quadruplexes that play key roles in telomere homeostasis and gene regulation $[15,16]$.

In a pathophysiological context, telomerase is essential for tumor progression and indeed, a high telomerase activity is observed in $80-90 \%$ of invasive metastatic tumors. This makes telomerase an important therapeutic target in hyperproliferative and other age-related conditions [17]. hTERT is switched off in differentiated cells, whereas hTERC is ubiquitously expressed in most tissues $[18,19]$. A vast number of transcription factors have been assumed to be involved in hTERT expression, most notably cMyc (together with estrogen), stimulating the expression of hTERT while in contrast Rb, p21 and CCCTC-binding factor (CTCF) have been implicated in hTERT suppression [20].

In addition to given sequence-based genetic pre-dispositions for age-related diseases [21,22], epigenetic regulation of gene expression and DNA stability and reversible changes therein are known to impact disease pathogenesis and progression, and should be increasingly trialed.

In recent decades, research has shown chemopreventive and antioxidative properties of a wide range of physiologically active plant-derived compounds. Anti-cancer effects have been reported including signaling pathways that address epigenetic mechanisms of inflammation, DNA repair and telomeric regulation [23]. In that respect, several phytochemicals such as curcumin, genistein or the polyphenol epigallocatechin-3-gallate (EGCG) studied here, have been shown to positively influence telomere length $[24,25,26]$. These natural bioactive compounds have the potential to act at multiple molecular target sites either directly through their antioxidative capacities or indirectly by affecting signaling pathways including DNA damage repair, 
epigenetic mechanisms or the mitogen activated protein (MAP) kinase pathway $[27,28]$.

The present work focused on EGCG as the most abundant polyphenol in green tea. With its eight phenolic groups EGCG not only has it been described for its marked antioxidative potential, but also for its ability to specifically impair cancer cell progression by blocking signal transduction pathways, and thereby suppressing telomerase activity $[18,19,29]$. These effects have been strongly connected to the inhibition of NF-KB activity, affecting a wide array of processes including MAP kinase-dependent- as well as growth factor-mediated pathways [30]. Next to these findings, EGCG has repeatedly demonstrated anti-proliferative effects by inducing apoptosis and cell cycle arrest in cancer cell studies [31,32,33].

In this context, our objective was to advance EGCG-targeted research by exploring the compound's effects on telomere regulation in both cancer and non-cancerous primary cells. We wanted to further evaluate positive effects in contrast to possible adverse impacts of high doses of EGCG. As green tea polyphenols are ingested and therefore have high relevance to the digestive tract as their first environment of interaction, this study's experiments were performed in colorectal adenocarcinoma Caco2 cells alongside ES-1 primary skin fibroblasts to unravel aspects of the cell type specific telomeric and redox activity of EGCG in vitro. Cell lines were treated with 20 and $200 \mu \mathrm{M}$ EGCG for 36, 72 and 144 hours, respectively and telomerase activity, relative telomere length as well as methylation status of hTERT and c-Myc were assessed to identify EGCGdependent alterations in the epigenetic regulation of telomeres. Malondialdehyde (MDA) served as a surrogate marker of lipid peroxidation.

\section{METHODS}

Cell culture: In this study, Caco-2 colorectal adenocarcinoma cells (DSMZ Leibniz Institute, Braunschweig, Germany) and primary human skin fibroblasts ES-1 (provided by the Institute of Cancer Research, Medical University of Vienna, Austria) were cultured to form monolayers in $25 \mathrm{~cm}^{2}$ filter cap tissue culture flasks (SPL Life Sciences Inc., Austria) in high glucose $(4.5 \mathrm{~g} / \mathrm{l})$ Dulbecco's modified Eagle medium (DMEM, PAA Austria) at $37^{\circ} \mathrm{C}$ in a humidified atmosphere of $95 \%$ ambient air and $5 \% \mathrm{CO}_{2}$. Media were supplemented with $5 \quad \% \quad(w / v)$ penicillin/streptomycin, $20 \%(\mathrm{v} / \mathrm{v})$ fetal bovine serum (FBS, PAA, Austria) and $1 \mathrm{ml}$ of $100 \mathrm{mM}$ Na-pyruvate. In all experimental setups, cells were passaged upon reaching $70 \%$ confluence, using Accutase ${ }^{\circledR}$ solution (2 $\mathrm{ml} /$ flask; Sigma Aldrich Austria). Experiments were conducted from passage 18 for Caco-2 and passage 17 for ES-1 fibroblasts.

Cell treatments: For treatments, Caco- 2 and ES-1 cells were seeded in 24-well plates. After 24 hours (h) initial incubation, cells were treated for a further 36 , 72 and 144 h, respectively, with different concentrations of EGCG (20 and $200 \mu \mathrm{M})$. For lipid peroxidation studies, $100 \mu \mathrm{M}$ EGCG was used. EGCG of the same grade and purity (> $95 \%$ ) was acquired as water soluble powder isolated from green tea leaves from Sigma Aldrich Austria and Biosysteme AG Zürich, respectively, and dissolved in Dulbecco's Modified Eagle Medium (DMEM, Sigma Aldrich Austria). DMEM served as vehicle control. For assessment of telomere length dynamics over time in Caco-2 cells, untreated cells were incubated for 36, 72, 96 and $192 \mathrm{~h}$ using the above- mentioned media conditions. Phenol red free media were used to avoid interference with MDA detection. For $\mathrm{H}_{2} \mathrm{O}_{2}$ induced oxidation (following $24 \mathrm{~h}$ 
of standard culture), cells were treated for $48 \mathrm{~h}$ with 250 and $500 \mu \mathrm{M} \mathrm{H} \mathrm{H}_{2}$, together with 20, 100 or $200 \mu \mathrm{M}$ EGCG. If not indicated elsewhere, cell treatment was carried out in quadruplicate in at least 3 independent experiments. Cell viability ( $\geq 85 \%$ live cells) was monitored for each time point using the trypan blue assay.

DNA Isolation: After incubations, cells were washed with cold PBS $\left(4^{\circ} \mathrm{C}\right)$ and detached using $150 \mu \mathrm{l}$ Accutase $^{\circledR}$ per well. After an additional washing step with PBS, DNA extraction was carried out using the DNA Mini Kit (Qiagen, Germany) following the manufacturer's protocol. DNA concentration was measured using a Pico100 UV/VIS spectrophotometer (Picodrop Ltd, Hinxton, UK).

Malondialdehyde (MDA) as marker of lipid peroxidation in Caco-2 cells: After harvesting, cell numbers were determined and MDA levels assessed using HPLC and fluorescence detection at $533 \mathrm{~nm}$ as previously described by Zappe et al. [34]. Resulting MDA levels were expressed as MDA concentration relative to cell number and calculated as ratio to untreated control.

Assessment of relative telomere length and telomerase activity: To determine relative telomere length (rTL), quantitative real-time polymerase chain reaction ( $q P C R)$ was conducted with primer sets targeting telomeres (T; ForwardTEL: 5'-CGGTTTGTTTGGGTTTGGGTTTGGGTTTGGGTTTGG

GTT-3' and ReverseTEL:

\section{5'GGCTTGCCTTACCCTTACCCTTACCCTTACCCTTACCCT}

$\left.-3^{\prime}\right)$ and the single copy control gene $(S)$, acidic ribosomal phosphoprotein 36B4 (Forward36B4: 5'ACTGGTCTAGGACCCGAGAAG-3' and Reverse36B4: 5'-TCAATGGTGCCTCTGGAGATT-3') as previously described by O'Callaghan and Fenech [35]. PCR results and CT mean values were analyzed using the StepOne Software $\mathrm{v} 2.3^{\mathrm{TM}}$ (Thermo Fisher). Relative telomere length was calculated based on the $2^{-\Delta \Delta C T}$ algorithm using the normalized (to positive control) difference in cycle threshold between telomere-and single copy gene samples. For calculations to be deemed valid, amplification efficiency between telomere and single copy gene samples must be approximately equal. [36]

Telomerase activity was determined by the Real-Time Quantitative Telomeric Repeat Amplification Protocol Assay combining a real-time PCR technique with the conventional TRAP method as previously described [37]. The assays were performed using individual protein extracts of both treated and untreated cells (DMEM \pm ECGC) after 36, 72 and 144 h. Telomerase activity was expressed as percentage of the activity of control cell extracts ( $0 \mathrm{~h}, 100 \%)$.

Bisulfite sequencing analysis: To assess the methylation status of nine auspicious CPG sites in the Telomerase Reverse Transcriptase (TERT) region, sodium bisulfite pyrosequencing was performed. Approximately $1 \mu \mathrm{g}$ of genomic DNA was used for bisulfite modification using the EpiTect-Bisulfite modification kit following the manufacturer's protocol (Qiagen, Austria). Modified DNA was then amplified by PCR using the GoTaq mix (Promega, Austria). DNA concentrations and purity were determined using a Pico100 UV/Vis spectrophotometer (Picodrop Ltd, Hinxton, UK). For analysis of nine CpGs in the promoter region of hTERT, PCR was performed with the following primers: Forward: 5'-GAGGGGTTGGGAGGGTT-3', Reverse: 5'-TССТАССССТТСАССТТССАA-3'. Analyzed 
CpGs were located at -184, -175, -173, -171, -164, $159,-154,-144,-136$ bp to the translational start site. The reverse primer was biotinylated. $30 \mu \mathrm{l}$ total volume for each reaction contained $15 \mu$ l PyroMark 2×PCR Master Mix (Qiagen), $3 \mu$ l CoralLoad (Qiagen), 5 pmol of each primer and $25 \mathrm{ng}$ of template DNA. The cycling program was performed with an initial denaturation step for $15 \mathrm{~min}$ at $95^{\circ} \mathrm{C}$, followed by 45 cycles of $94{ }^{\circ} \mathrm{C}$ for $30 \mathrm{~s}, 56{ }^{\circ} \mathrm{C}$ for $30 \mathrm{~s}$ and $72{ }^{\circ} \mathrm{C}$ for $10 \mathrm{~s}$ each and a final elongation of $10 \mathrm{~s}$ at $72{ }^{\circ} \mathrm{C}$. Subsequently, sequencing was performed on a PyroMark Q24 MDx work station (Qiagen) using a specific sequencing primer: 5'-ССТTСАССТTССААСТ-3'.

High Resolution Melting analysis: CpG methylation of the $c-M y c$ promoter region was assessed by using the method of Methylation-Sensitive High-Resolution Melting (MS-HRM), differentiating sequences based on their melting behavior that is dependent on GC content. The reaction mix contained $5 \mu l$ MeltDoctor $^{\mathrm{TM}}$ HRM Master Mix 5-10 pmol/ $\mu \mathrm{l}$ of each primer, $10 \mathrm{ng}$ bisulfite converted DNA, $2 \mathrm{mM} \mathrm{MgCl} 2$ and RNase-free water. PCR was conducted with the following primers, previously described by Rahat et al. [38]: Forward 5'-TGAGGATTTTCGAGTTGTGTTGT-3' and Reverse

5'-CTTCTCGAAACAAAAAAAAAACCAAAA-3'. For MSHRM a Rotor-Gene ${ }^{\circledR} \mathrm{Q}$ (Qiagen) including a 72-well rotor was used, PCR amplification was performed with one step of $95^{\circ} \mathrm{C}$ for $10 \mathrm{~min}, 40$ cycles of $95^{\circ} \mathrm{C}$ for $15 \mathrm{~s}$ and $58^{\circ} \mathrm{C}$ for $1 \mathrm{~min}$ each, followed by $95^{\circ} \mathrm{C}$ for $10 \mathrm{~min}$ and $60^{\circ} \mathrm{C}$ for $1 \mathrm{~min}$. HRM was conducted with a continuous acquisition to $90^{\circ} \mathrm{C}$ with increments of $0.1^{\circ} \mathrm{C}$. Fully methylated and unmethylated methylation standards were acquired commercially (Qiagen) and bisulfite conversion was conducted as described above. Standards were prepared to obtain following ratios of methylation: 5.5, 8, 12.5, 25, 50 and $100 \%$. HRM runs were analyzed with Rotor Gene Software Q (Qiagen). Normalized relative fluorescence units were imported to Prism 6 (Graphpad) and area under the curve (AUC) was calculated as described previously by Switzeny et al. [39]. Linear regression of standard AUC was then used to interpolate methylation of unknown samples.

Statistical Analysis: Treatment effects were tested by a two-way ANOVA followed by Sidak's multiple comparisons test, or a two-samples t-Test using the GraphPad Prism6 software. Statistical significance $\left({ }^{*}\right)$ was based on a $95 \%$ level of confidence ( $p$-value $\leq$ $0.05)$.

\section{RESULTS}

Associations of EGCG-treatment and telomeric modulation are inverted between cancerous and normal cells: Relative telomere length was assessed in ES-1 and Caco-2 cells at 36, 72 and 144 h, respectively, following treatment with 20 or $200 \mu \mathrm{M}$ EGCG or DMEM only for controls. After 72 and $144 \mathrm{~h}$ incubation with EGCG a higher rTL was found in ES-1 cells compared to the untreated control, with an significant increase after the $144 \mathrm{~h}$ incubation time ( $p=0.01)$ (Table 1, Fig. 1).

In Caco-2 cells, significant differences were found after $36(p=0.03)$ and $72 h(p=0.02)$ incubation. High-dose EGCG $(200 \mu \mathrm{M})$ was associated with a significant decrease in rTL compared to untreated controls. For incubation with $20 \mu \mathrm{M}$ EGCG no significant changes in rTL were seen in both cell lines. 
Table 1. Relative telomere length in ES-1 human fibroblasts and Caco-2 adenocarcinoma cells after 36, 72 and $144 \mathrm{~h}$ treatment with $200 \mu \mathrm{M}$ EGCG over untreated control (DMEM).

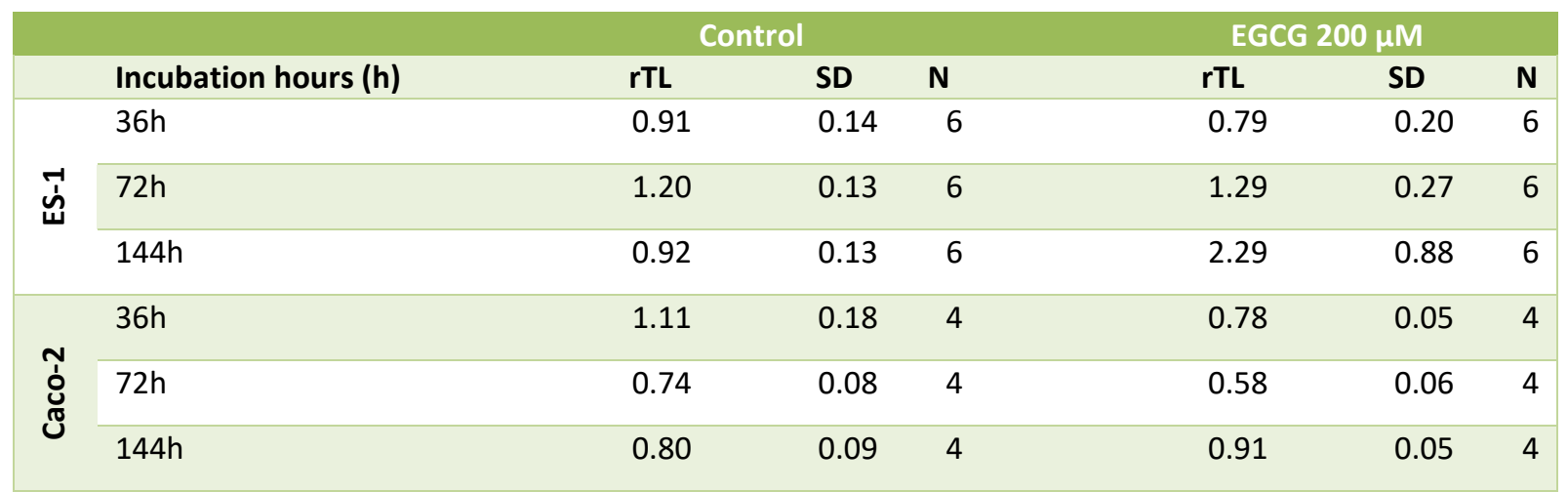

Values of rTL are expressed as means.

A

ES-1

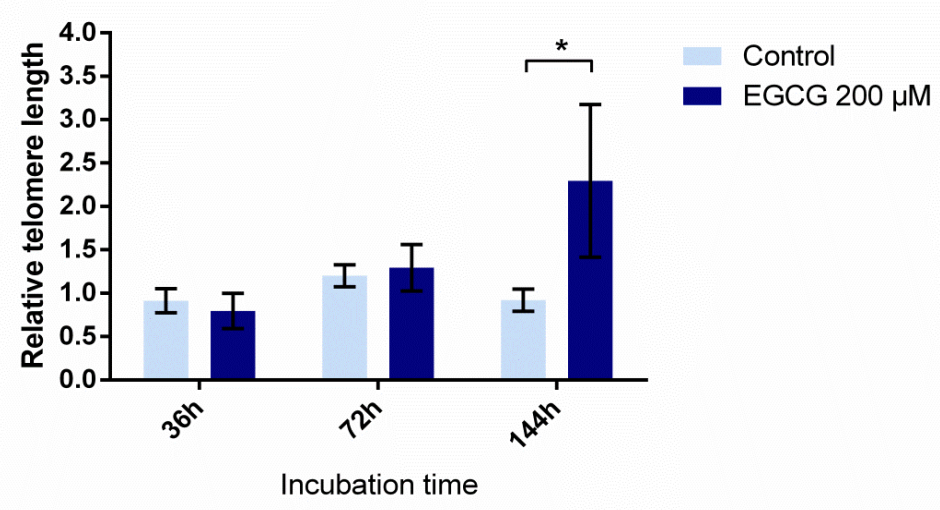

B

Caco-2

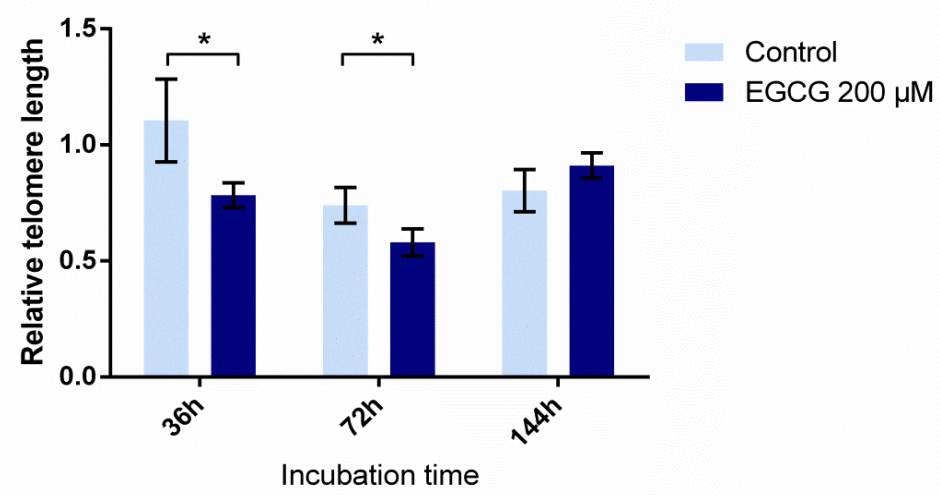

Figure 1. Relative telomere length in 2 different human cell lines with and without treatment with epigallocatechin gallate (EGCG). (A) and (B): Bar graphs show relative telomere length from human fibroblasts ES-1 and Caco-2 colorectal adenocarcinoma cells after 36,72 , and $144 \mathrm{~h}$ incubation with $200 \mu \mathrm{M}$ EGCG compared to vehicle (DMEM) control. Relative telomere length was analyzed by $\mathrm{PPCR}$ and calculated based on the $2^{-\triangle \Delta C T}$ algorithm using the difference in cycle threshold between telomere- and single copy gene 36B4, normalized to an untreated positive control. Cell treatment with EGCG was carried out in quadruplicate in at least 3 independent experiments. Statistical significance was checked by two-way ANOVA followed by Sidak's test for multiple comparisons as well as two-samples t-Test using GraphPad Prism6 software. P-values of smaller than 0.05 are indicated by one asterisk. 
Relative telomerase activity is affected after EGCG

treatment in Caco-2 cells: Telomerase activity was assessed using the Real-Time Quantitative Telomeric Repeat Amplification Protocol Assay and expressed as percentage of telomerase activity of control cells ( $0 \mathrm{~h}$, $100 \%)$. Fibroblasts and other healthy somatic cells are reported to have undetectable or very low telomerase activity $[40,41]$. In agreement, we too observed minute levels of telomerase activity in ES-1 fibroblasts of just above detection limit. In untreated Caco-2 cancer cells telomerase activity decreased over time from $15.28 \% \pm 5.45$ after 36 h, to $13.36 \%$ \pm 0.22 after $72 \mathrm{~h}$ and to $2.52 \% \pm 0.08$ after $144 \mathrm{~h}$ incubation. Compared with untreated controls, we found a significant response to $200 \mu \mathrm{M}$ EGCG in Caco2 cells resulting in reduced telomerase activity values of $1.04 \% \pm 0.05$ (36h, $p \leq 0.0001), 0.86 \% \pm 0.03$ (72 h, $\mathrm{p} \leq 0.0001)$ as well as $0.551 \% \pm 0.06(144 \mathrm{~h}, \mathrm{p} \leq 0.01)$

(Fig. 2).

The methylation status of hTERT varies between test conditions and cell type: Sodium bisulfite pyrosequencing was performed to assess the methylation status of nine auspicious CpG sites in the hTERT-region. Calculated mean percental (\%) methylation levels of the hTERT promoter of Caco-2 untreated controls at 36,72 and $144 \mathrm{~h}$ were $49.66 \pm$ $2.21,48.13 \pm 1.86$, and $48.73 \pm 1.73$, respectively (Fig. $3 \mathrm{~A}$ and $3 \mathrm{~B})$. The $h T E R T$ methylation status of those Caco-2 cells receiving treatment remained unaffected irrespective of the duration or dosage of treatment with values $(\%)$ of $49.98 \pm 2.63$ or $47.82 \pm 1.16$ after $36 \mathrm{~h}$ or $72 \mathrm{~h}$ incubation with $200 \mu \mathrm{M}$ EGCG (Fig. 3A).

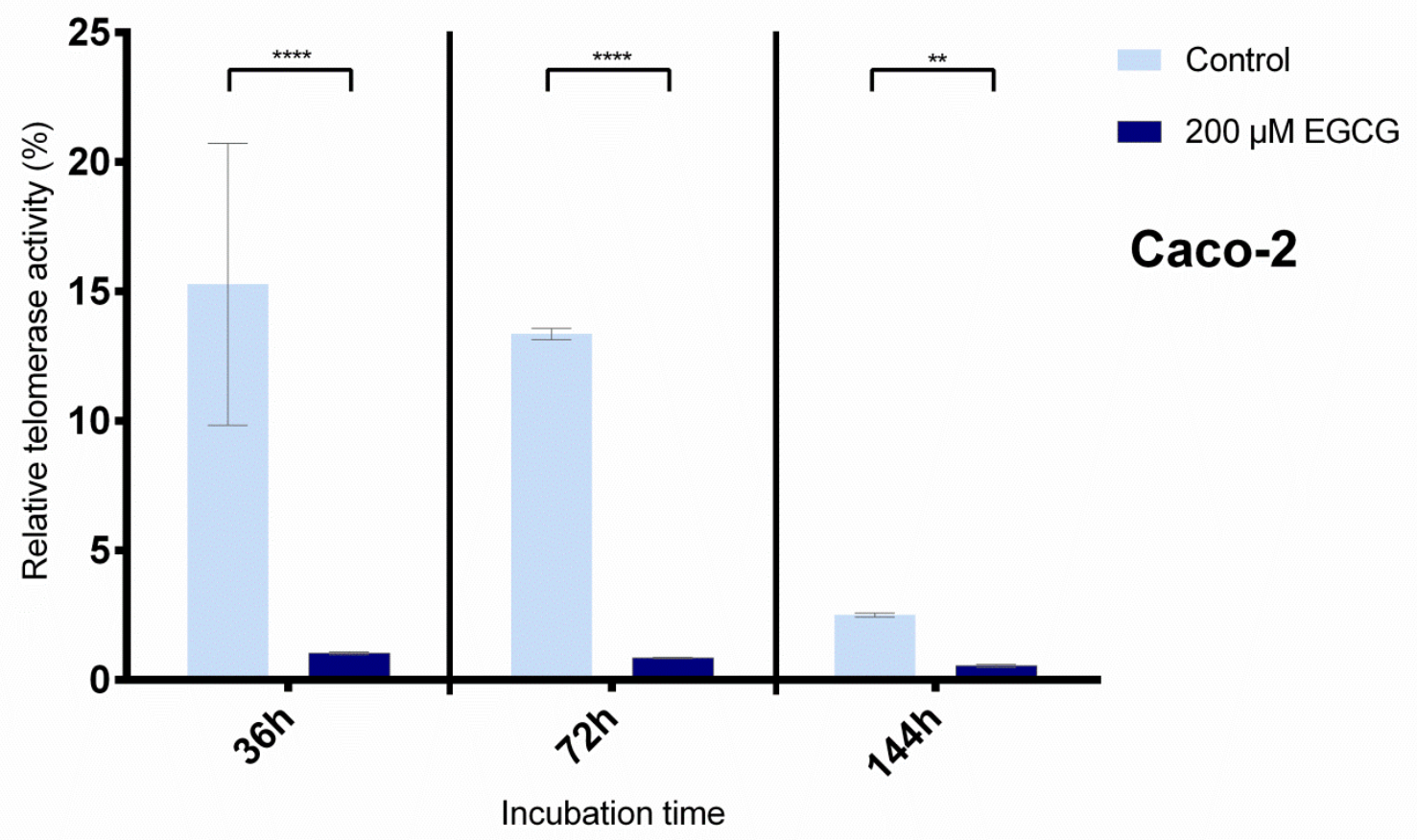

Figure 2. Effects of EGCG treatment on telomerase activity in Caco-2 colorectal cancer cells. Columns display telomerase activity in Caco-2 cancer cells after 36, 72, and $144 \mathrm{~h}$ incubation with $200 \mu \mathrm{M}$ EGCG compared to an untreated control. Telomerase activity was measured using the Real-Time Quantitative Telomeric Repeat Amplification Protocol Assay combining a real-time PCR technique with a conventional TRAP method. Activity is expressed as percentage of the activity in the control cells (0h, $100 \%)$. Statistical significance was indicated by two-way ANOVA followed by Sidak's test for multiple comparisons as well as the twosamples t-Test using GraphPad Prism6 software. P-values: $<0.05\left({ }^{*}\right),<0.01\left({ }^{* *}\right), \mathrm{p}<0.001\left({ }^{* * *}\right)$, and $\mathrm{p}<0.0001\left({ }^{* * * *}\right)$. 
A hTERT promoter methylation in Caco-2

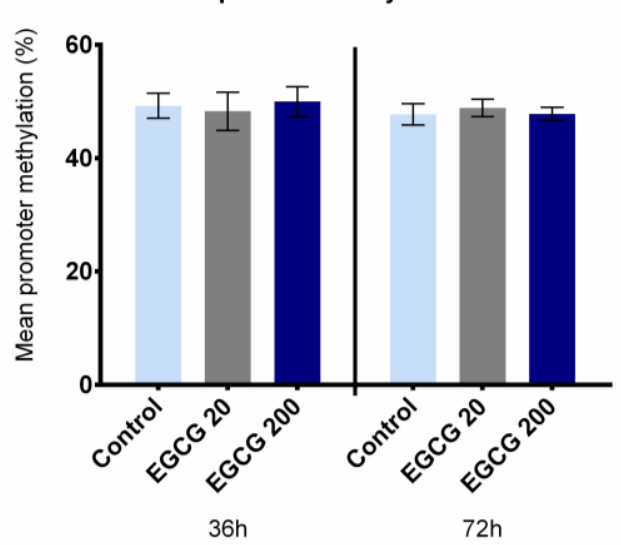

C hTERT promoter methylation in ES-1

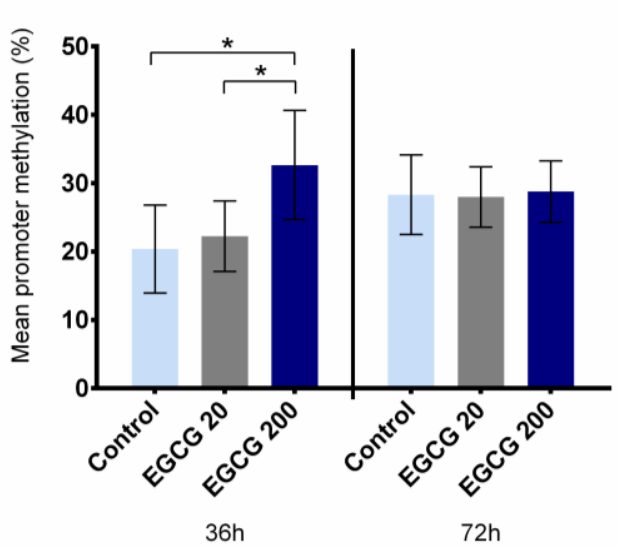

B

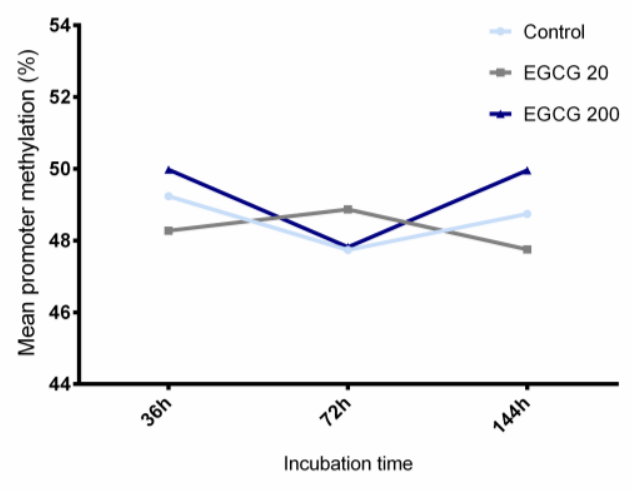

D

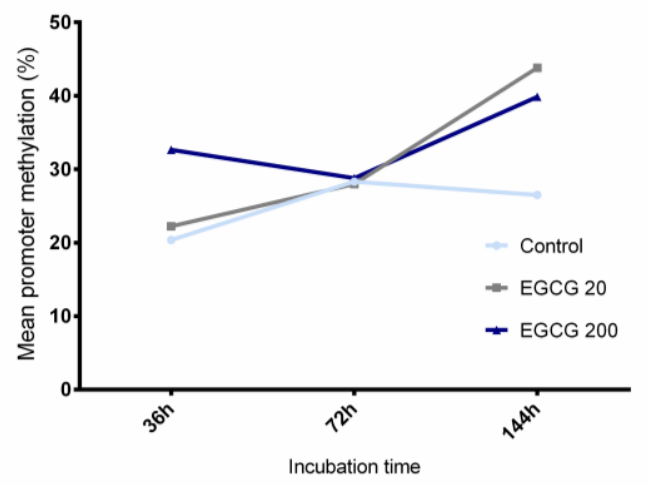

Figure 3. Mean promoter methylation of $h T E R T$ in Caco-2 cancer cells and ES-1 primary fibroblasts after incubation with different doses of EGCG. (A) and (C) show mean methylation percentages \pm SD of $h T E R T$, (B) and (D) depict mean values for each group after 36,72 and $144 \mathrm{~h}$ incubation with 20 or $200 \mu \mathrm{M}$ EGCG compared to untreated DMEM control. Methylation status was assessed by sodium bisulfite pyrosequencing. Statistical significance was indicated by the two-samples t-Test using GraphPad Prism6 software. P-values less than 0.05 are indicated by one asterisk; ( $\mathrm{n}=6$ per group).

The findings were somewhat different for ES-1 fibroblasts. Mean percental promoter methylation of hTERT in ES-1 cells after 36,72 and $144 \mathrm{~h}$ incubation were found to be $20.36 \pm 6.45,28.31 \pm 5.82$ and 26.49 \pm 13.99. After incubation with $200 \mu \mathrm{M}$ EGCG, a significantly higher methylation was found after 36 and $144 \mathrm{~h}$ compared to untreated controls with values of $32.64 \pm 8.00$ and $39.86 \pm 4.75$, respectively $(p \leq 0.01$ ) (Fig. 3C and 3D).

Analyzing the methylation status of $9 \mathrm{CpG}$ sites within the $h T E R T$ promoter region, revealed a significant result in fibroblasts concerning CpG 1-6 after $36 \mathrm{~h}$ incubation with $200 \mu \mathrm{M}$ EGCG (Fig. 4B). This effect was also evident after $144 \mathrm{~h}$, with significantly lower methylation values in the $200 \mu \mathrm{M}$ EGCG treatment group in $\mathrm{CpG} 1,2,3,4$ and 6. While mean
hTERT methylation in Caco-2 cells was significantly higher than in ES-1 fibroblasts $(p<0.001)$, and all CpG sites in ES-1 cells analyzed showed lower methylation than in Caco-2 cells $(p<0.001)$, no significant changes in the methylation status upon EGCG treatment were found in Caco-2 cells (Fig. 4A).

Methylation status of c-Myc in Caco-2 cells changes after incubation with EGCG: The percental methylation status of the $c-M y c$ promoter region was analyzed by MS-HRM in Caco-2 cancer cells and ES-1 primary fibroblasts after 36,72 , or 144 hours incubation with 20 and $200 \mu \mathrm{M}$ EGCG, respectively, and compared to untreated controls. Significantly higher $c-M y c$ promoter methylation was found in Caco-2 cells after $36 \mathrm{~h}$ treatment with EGCG at both 
concentrations compared to untreated control $(p \leq$ 0.01) (Fig. 5A). In contrast, EGCG incubation hardly affected the $c-M y c$ methylation status of ES-1 fibroblasts (Fig. 5B): Control fibroblasts had methylation levels (\%) ranging from $6.89 \pm 1.15$ (at 36 h), over $7.52 \pm 0.23$ (at 72 h) to $3.45 \pm 0.99$ (at 144 h).
After incubation, values reached $7.99 \pm 0.86(20 \mu \mathrm{M}$ EGCG), $8.31 \pm 1.53$ (200 $\mu \mathrm{M}$ EGCG) after 36 hours,

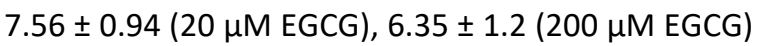
after 72 hours and $5.29 \pm 0.82(20 \mu \mathrm{M}$ EGCG) as well as $3.6 \pm 0.33$ (200 $\mu \mathrm{M}$ EGCG) after 144 hours.

\section{A Caco-2 36h}

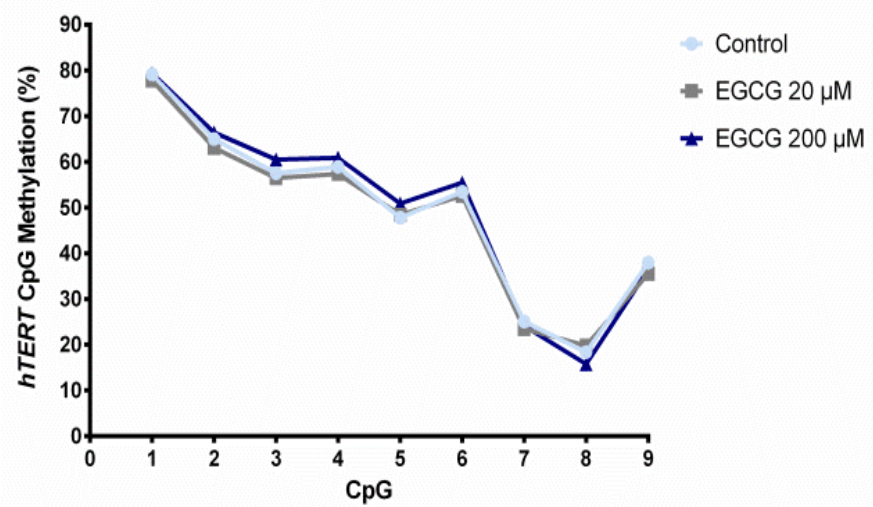

B ES-1 36h

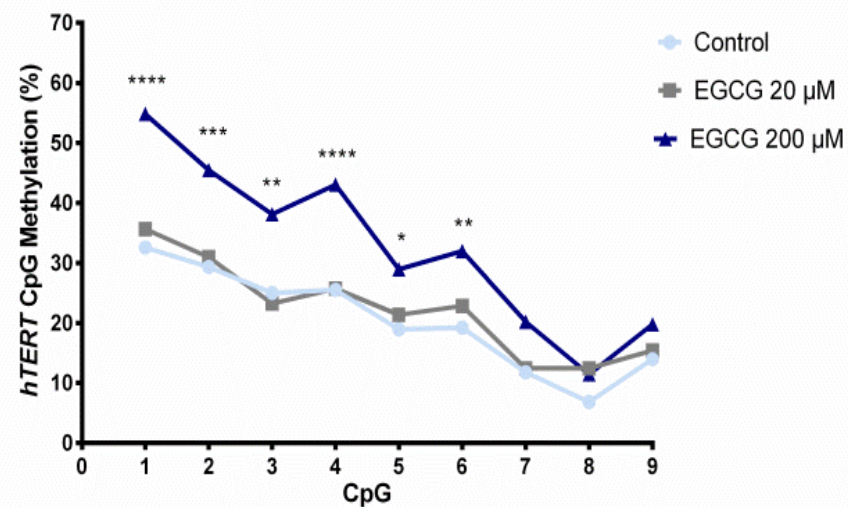

Figure 4. Effect of EGCG treatment on CpG promoter methylation of $h T E R T$ in Caco-2 cells and ES-1 fibroblasts. The line charts display the methylation status of $9 \mathrm{CpG}$ sites within the $h T E R T$ promoter region analyzed by sodium bisulfite pyrosequencing in Caco-2 cells (A) and ES-1 fibroblasts (B) after $36 \mathrm{~h}$ incubation in 3 groups (non treatment control, 20 and $200 \mu$ M EGCG). Significant effects of EGCG treatment with at CpG 1-6 are labeled with asterisks. Statistical significance was indicated by two-way ANOVA followed by Sidak's test for multiple comparisons as well as the two-samples t-Test using GraphPad Prism6 software. P-values: $<0.05(*),<0.01(* *), p<0.001(* * *)$, and $\mathrm{p}<0.0001(* * *)$; ( $\mathrm{n}=6$ per group).

\section{c-Myc promoter methylation}

A Caco-2

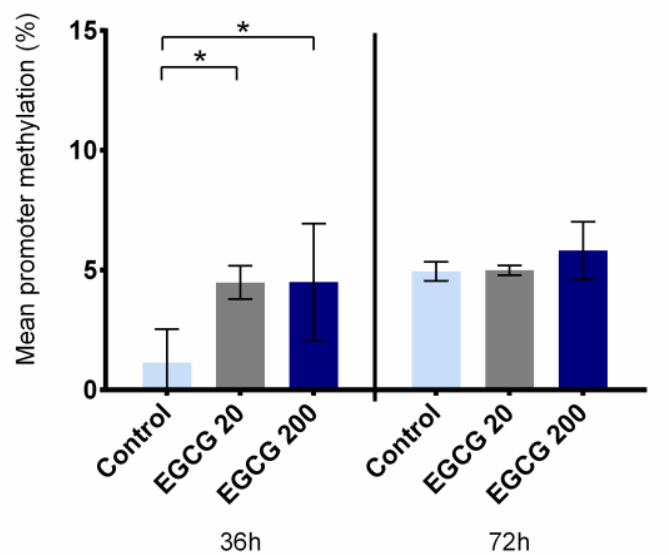

B ES-1

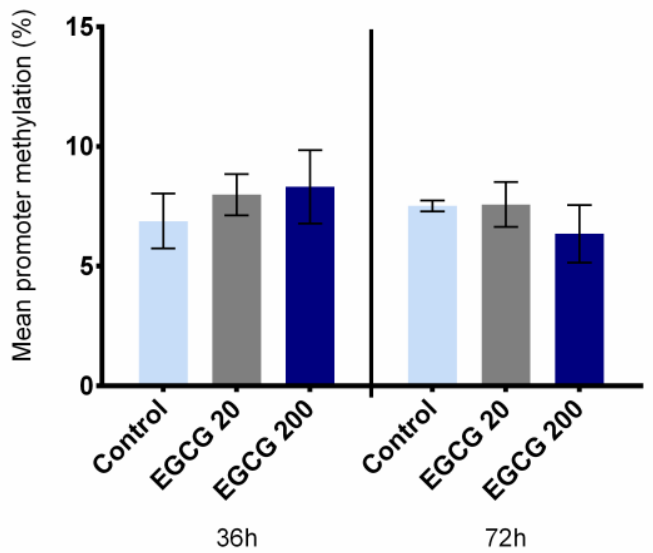

Figure 5. Changes in mean promoter methylation of $c-M y c$ in Caco-2 cancer cells and ES-1 primary fibroblasts after incubation with EGCG. Methylation status of $c-M y c$ promoter region in Caco-2 cells (A) and ES-1 fibroblasts (B) after $36 \mathrm{~h}$ and $72 \mathrm{~h}$ incubation in 3 groups (non treatment control, $20 \mu \mathrm{M}$ and $200 \mu \mathrm{M} \mathrm{EGCG)} \mathrm{analyzed} \mathrm{by} \mathrm{Methylation-Sensitive} \mathrm{High} \mathrm{Resolution}$ Melting (MS-HRM). Statistical significance compared to untreated control was observed in Caco-2 cells after $36 \mathrm{~h}$ treatment with EGCG in both concentrations. Significance was assessed by the two-samples t-Test using GraphPad Prism6 software. P-values of less than 0.05 are indicated by one asterisk ( $n=8$ per group). 
EGCG counteracts cellular oxidative stress: In Caco-2 cells sole treatment with 250 and $500 \mu \mathrm{M} \mathrm{H}_{2} \mathrm{O}_{2}$, respectively, significantly increased MDA levels versus the untreated control (Fig. 6, left panel). Similarly, two separately tested high EGCG concentrations (100 and $200 \mu \mathrm{M})$ increased MDA levels, but only by trend (Fig. 6, middle panel).
Conversely, a low concentration of EGCG $(20 \mu \mathrm{M})$ alone significantly decreased MDA levels versus the untreated control (Fig. 6, middle panel). The same was true for EGCG $(20,100$ and $200 \mu \mathrm{M})$ in simultaneous combination with $\mathrm{H}_{2} \mathrm{O}_{2}$, attenuating lipid peroxidation, and resulting in decreased MDA levels (Fig. 6, right panel).

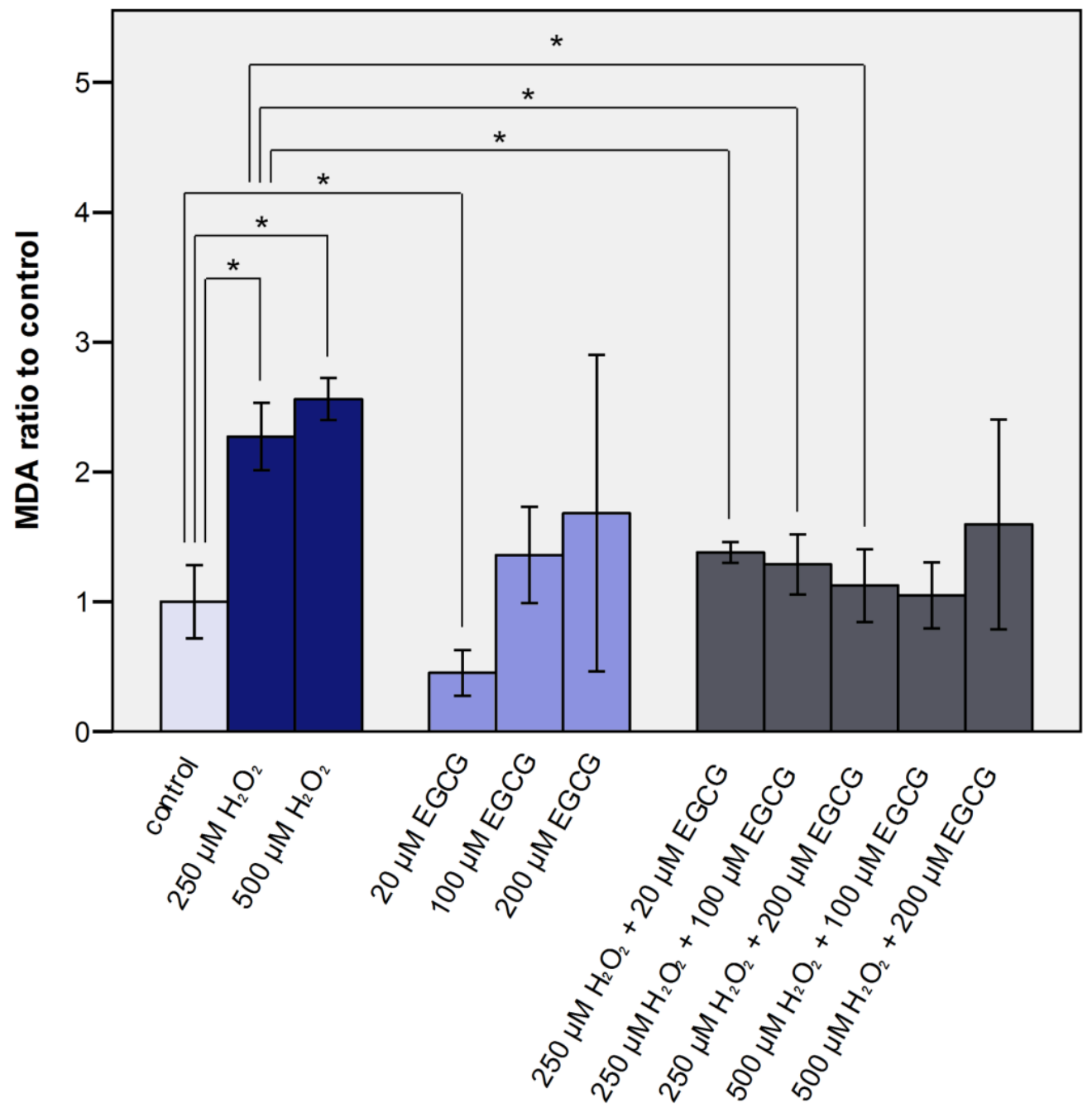

Figure 6. Pro- and antioxidative effects of EGCG in Caco-2 cells assessed by MDA levels as marker for lipid peroxidation. MDA levels in Caco-2 cells after incubation with 20, 100 and $200 \mu \mathrm{M}$ EGCG analyzed by HPLC and fluorescence detection at $533 \mathrm{~nm}$. For $\mathrm{H}_{2} \mathrm{O}_{2}$ induced oxidation 250 and $500 \mu \mathrm{M} \mathrm{H}_{2} \mathrm{O}_{2}$, respectively were used. Bar charts display mean MDA \pm SD over respective untreated controls. Significance was assessed by the two-samples t-Test using GraphPad Prism6 software. Experiments were independently repeated. P-values of less than 0.05 are indicated by one asterisk.

\section{DISCUSSION}

Predicated on EGCG's reported in vitro antioxidant and chemo-preventive activities, recent topical research has increasingly focused on the compound's potential molecular role in cancer treatment. While EGCG has been reported to interact with over 300 
proteins at a molecular level, stoichiometric information remains scarce [42]. However, studies suggest EGCG exerts its proposed anti-proliferative (i.e. "anti-cancer") effects in a highly targeted manner exclusively on cancer cells, while omitting their healthy counterparts, by selectively regulating carcinogenic signaling pathways $[19,29,43,44]$. These include a plethora of targets, as recently reviewed by Negri et al. [45]. Indeed, other mechanistic studies observed a dose-dependent association between EGCG and telomere length in normal cells and conversely, decreased telomerase levels and $h T E R T$ gene expression in cancer cells [24,29], supporting EGCG's proposed selective anti-proliferative effects.

It is well accepted, that telomere shortening occurs in most human somatic cells with each DNA replication cycle, ultimately leading to cellular senescence or apoptosis. Cell division also increases the likelihood of replication mistakes to occur that might or might not be relevant in the pathogenesis of age-related diseases such as cancer. Indeed, a loss of telomeric integrity affects the replicative capacity of all cells of the body and triggers global epigenetic alterations impacting chromatin and transcriptional properties, accelerating cellular senescence and aging along with age-related health conditions. Conversely, cancer cells maintain their telomeres by expressing telomerase or activating the alternative lengthening of telomeres pathway [46], and moreover, recent studies have shown a strong correlation of long telomeres with different types of cancer, e.g. caused by mutations in the shelterin complex $[47,48]$. However, research has indicated that the mean telomere length of telomerase-positive cancer cells such as Caco-2 is stable [49]. Intriguingly, this finding supports and complements the phenomena of telomere shortening and decrease in telomerase activity encountered upon EGCG treatment of Caco-2 cells in this study. To identify EGCG-dependent alterations in the epigenetic control of telomeres, we analyzed methylation of $h T E R T$ and the protooncogene c-Myc, due to its close link to hTERT gene expression. As the $h T E R T$ promoter is highly enriched in $\mathrm{CpG}$ dinucleotides, in the context of methylation analyses, different regions have been described. Though DNA methylation studies of hTERT have generated inconsistent data, hypermethylation of the upstream of the transcription start site (UTSS) region has been strongly associated with TERT expression in cancers [50]. At -165 and +44 E-boxes are found, which are binding sites for c-Myc and Mad1 [51], therefore CpG methylation analysis was conducted in this area to target possible interactions with c-Myc.

Through its demonstrated ability to inhibit 5cytosine DNA methyltransferase (DNMT) [18] and histone deacetylases (HDAC) [30], a regulatory epigenetic role for EGCG has been revealed. Topical research found EGCG suppresses telomerase activity in cancer cells, ultimately halting tumor proliferation $[29,52]$. In that respect, hypomethylation of genomic DNA alongside gene-specific hypermethylation in methylation-sensitive CpG islands of promoter regions of relevant genes have been reported $[53,54,55]$. CpG hypermethylation in the CTCF binding region of the promotor region of $h T E R T$ results in a decreased binding affinity of the repressor CCCTCbinding factor (CTCF) and increased expression of the catalytic subunit of hTERT [20]. Interestingly, hypermethylation of the $h T E R T$ gene has been correlated with telomerase activity in both healthy and tumor tissues, while conversely, demethylation was not associated with increased hTERT expression [56]. Although a series of transcription factors and pathways have been implicated in the regulation of hTERT expression, CTCF appears to be a correlated key determinant of mortality [20]. While in the 
present study merely non-consistent changes in the methylation status of nine auspicious CpG sites were found following EGCG incubation of Caco-2 cells, we located six significantly hypermethylated CpG sites in normal fibroblasts, as well as a significantly higher overall mean methylation status of hTERT after treatment with $200 \mu \mathrm{M}$ EGCG, both after $36 \mathrm{~h}$ and 144 h. These findings emphasize a role for EGCG in regulating telomeres and ultimately cellular aging. Unexpectedly, at $72 \mathrm{~h}$ incubation, significant methylation differences of control and treated cells were not apparent in fibroblasts. We hypothesize, this finding might be ascribed to the proposition that the overall methylation status in cell lines is dynamic (i.e. changes over time) depending on cell line and environmental factors $[57,58]$.

c-Myc, for which the hTERT promoter contains a binding site, is considered a "master regulator" of tumorigenesis controlling many aspects of cell proliferation, differentiation and cellular metabolism [59]. Reportedly, activation of $c-M y c$ is observed in more than half of human cancers and its dysregulation is a proposed marker for genomic instability $[59,60,61]$. The critical connection of $c-M y c$ expression and EGCG was recently established [62], demonstrating a significant decrease of $c-M y c$ expression along with reduced hTERT protein levels after treatment with EGCG in an immortal cell line. Signaling through NF-KB has been proposed as a possible underlying mechanism. Thus, we adopted methylation of $c-M y c$ with regard to its indirect ability to regulate telomerase through hTERT. We found that, versus respective controls, $c-M y c$ methylation was hardly affected in fibroblasts whereas significantly higher methylation, likely resulting in decreased c-Myc mRNA expression, was found in Caco- 2 cells after $36 \mathrm{~h}$ treatment with EGCG. These results underline the multifaceted molecular effects of EGCG reported, emphasizing the compound's highly specific possible chemotherapeutic relevance.

As mentioned above, interestingly, the methylation status of $h T E R T$ in Caco-2 cells was but little affected, neither by time nor treatment with EGCG. However, similar to an earlier report on HeLa cervical cancer cells [19], a significant decrease in relative telomere length and a decline in telomerase activity was observed after EGCG treatment. Therefore, we suggest that telomere shortening might be indirectly further enhanced by EGCGmediated inhibition of telomerase, through generation of ROS. While the exact effects of ROS on telomerase are not well understood to date, oxidative-stress-induced functional inhibition of telomerase in cancer cells has been reported recently [63]. Telomeric DNA itself is thought to be particularly susceptible to ROS-mediated damage along with telomeric attrition, both of which are exacerbated by treatment with EGCG which furthermore has been shown to exhibit genotoxicity in a telomereindependent fashion [64].

Regardless of the exact underlying mechanisms, reportedly the biological effects of EGCG follow a concentration-dependent pattern [65]. Overall, concentrations of 10-200 $\mu \mathrm{M}$ EGCG exerted antiproliferative effects in human cancer cell cultures from different tissues $[33,66,67,68,69]$. In our study, dose-dependency was confirmed in that $200 \mu \mathrm{M}$ EGCG proved to be more efficacious than $20 \mu \mathrm{M}$ regarding telomeric regulation in Caco-2 cells.

While physiological concentrations of EGCG (< $10 \mu \mathrm{M}$ ) have been reported to stabilize metabolic function and assist in the management of oxidative stress $[65,70,71]$, experimental evidence suggests cancer inhibition might require higher doses $[69,72]$. Despite this proposition, inversely, other studies have raised concern over possible adverse effects of EGCG 
when used at high concentrations [73,74,75]. Therefore, potential future clinical applications must include strategies and techniques that effectively and safely deliver EGCG exclusively to target sites while limiting unwanted (systemic) side effects. Recently, research groups have successfully explored nanotechnology-inspired methods using encapsulated EGCG, which demonstrated increased bioavailability and functional selectivity at the target site, and ultimately a reduction in tumor growth [76,77]. Albeit, before EGCG as a compound with possible therapeutic effects can find its way into the clinic, several issues need to be resolved. For instance, EGCG has been shown to undergo a whole range of complex structural changes in vivo and oxidatively polymerize in cell culture. This results in cell-specific oxidative environments in hyperproliferative versus normal cells $[78,79]$. Autooxidation of EGCG is reported to produce ROS in a dose-dependent manner [80]. Low concentrations (< $5 \mu \mathrm{M}$ ) have been associated with the promotion of cell growth, whereas abundance of ROS resulting from the use of high EGCG concentrations (> $50 \mu \mathrm{M}$ ) provoked apoptotic and inhibitory effects including a reduction of telomerase activity $[79,80,81]$, as was also demonstrated in the present study, and emphasized by the additional finding of telomere shortening. However, it remains to be fully clarified whether suchlike auto-oxidative properties of EGCG can also occur at organ sites in vivo [80], and which potential risk this might pose to macromolecules such as proteins or lipids.

To shed some light on this issue, we assessed malondialdehyde (MDA) levels $[73,74]$ in Caco-2 cells to obtain a first indication of potential pro-oxidative effects of EGCG in a physiologically relevant tissue model. MDA is a well-accepted and widely used surrogate marker of tissue lipid peroxidation (i.e. oxidative stress) $[24,34,82,83,84]$. Measuring MDA formation in our cell culture systems enabled us to assess possible adverse effects of high doses of EGCG on the one hand, but also identify the compound's potential to inhibit peroxidation induced by $\mathrm{H}_{2} \mathrm{O}_{2}$ on the other hand. In accordance with earlier literature [85], EGCG alone at low concentration $(20 \mu \mathrm{M})$ significantly decreased MDA levels, while high concentrations (100 and $200 \mu \mathrm{M}$, respectively) were non-significantly associated with increased MDA levels. When combined with $\mathrm{H}_{2} \mathrm{O}_{2}$, EGCG quenched $\mathrm{H}_{2} \mathrm{O}_{2}$-induced lipid peroxidation. Similar findings had been reported earlier for human dermal fibroblasts where EGCG decreased MDA levels [86]. Measurement of basal and $\mathrm{H}_{2} \mathrm{O}_{2}$-induced ROS production, glutathione (GSH/GSSH) or other related oxidative stress biomarkers could help evaluate the cellular antioxidant response and the extent and quality of EGCG's antioxidant potential in future research. However, there is consensus, that the antioxidant property of EGCG is mediated by many different mechanisms including the activation or inhibition of enzymes involved in the modulation of ROS levels.

As regards the latter, the sirtuins enzyme family (SIRTs) has been intensively studied because of their increasing significance in cancer biology and other age-associated diseases [3]. SIRTs (SIRT1-SIRT7), are nicotinamide adenine dinucleotide (NAD+) dependent histone deacetylases, which modulate the regulation of a variety of inflammatory and metabolic pathways, including those associated with redox signaling $[87,88,89]$. Though both sirtuins and telomeres are heavily implicated in ageing related processes, their molecular interplay is not fully understood. However, recent studies support tightly intertwined mechanisms for different sirtuin subgroups in telomeric regulation in part because of 
their nuclear localization [88,90,91,92]. Furthermore, SIRT1 is reported to interact with transcription factors related to the $h T E R T$ promoter [93] and deacetylates the C-terminus of c-Myc, additionally affecting $h T E R T$ promoter activity [94]. As regards the activation of sirtuins, there could be a role for polyphenols [87,95], as also demonstrated recently by us using 3T3-L1 preadipocytes [96].

Recently, rapidly emerging scientific findings about the interplay of microRNAs (miRNAs) with hTERT have shed new light on the regulation of telomeres [97]. Also in this context, polyphenols such as EGCG constitute potential modulators especially in cancer cells, as they have been shown to regulate miRNA expression [98,99].

\section{CONCLUSIONS}

Telomere regulating effects of EGCG are on account of several related mechanisms that include antioxidant properties, activation of sirtuins, miRNAs and the modulation of signaling pathways, such as NF-KB.

Our study confirms EGCG's proposed antioxidative properties in vitro by exerting a protective effect against $\mathrm{H}_{2} \mathrm{O}_{2}$-induced lipid peroxidation, demonstrated by decreased MDA levels in Caco- 2 cells. At the same time, pro-oxidant effects of high doses of EGCG could constitute a possible mechanism for the opposed modulation of telomeres by EGCG in cancer versus normal cells. As EGCG is known to play an active role in modulating cell metabolism and apoptosis, selectively targeting the telomerase gene and telomeres in cancer cells, our observations are in line with earlier reports and emphasize a potential role for EGCG in reinforced novel anti-cancer drugs [100]. Despite those promising results it must be considered that effects are strongly affected by cell type characteristics, cell systems and culture conditions. Cell lines reflect their respective tissue origin in their different potential of DNA repair capacity and clearance of $\mathrm{H}_{2} \mathrm{O}_{2}$ and intracellular ROS generation, also resulting in a specific susceptibility to phyto-/chemicals such as dietary compounds $[80,101,102]$.

Future research including but not limited to an in-depth characterization of active enzymes that are selectively expressed in EGCG treated cells will assist in understanding EGCG's mode of action in physiological and pathological conditions. Plantderived compounds like EGCG may eventually offer promising new treatment options for degenerative and hyperproliferative diseases. For this to happen, in vivo models are a crucial prerequisite to clarify EGCG's pharmacological potential, assess its bioavailability, ideal route/dosage of administration and safety.

List of Abbreviations: bp, base pairs; CTCF, CCCTCbinding factor; DMEM, Dulbecco's modified Eagle medium; DNMT, 5-cytosine DNA methyltransferase; EGCG, Epigallocatechin gallate; FBS, fetal bovine serum; GSH, glutathione (GSH/GSSH); HDAC, histone deacetylases; HPLC, High Performance Liquid Chromatography; hTERT, human Telomerase Reverse Transcriptase; MAP, mitogen activated protein; MDA, malondialdehyde; miRNAs, microRNAs; MS-HRM, methylation-sensitive high-resolution melting; NF-KB, Nuclear factor kappa B; NAD+, nicotinamide adenine dinucleotide; ROS, reactive oxygen species; rTL, relative telomere length; SIRT, sirtuin; UTSS, upstream of the transcription start site.

Author's Contributions: Angelika Pointner, Alexander Haslberger and Ulrich Magnet conceived the presented idea. Angelika Pointner, Katja Zappe and Ulrich Magnet developed the theory, performed the experiments and verified the analytical methods. 
Angelika Pointner took the lead in writing the manuscript. Alexander Haslberger encouraged Angelika Pointner to investigate the topic and supervised the findings of this work. Christine Mölzer, Anela Tosevska and Ulrike Krammer contributed to experiments regarding telomeres and cell lines. Angelika Pointner, Alexander Haslberger, Christine Mölzer, Berit Hippe, Elisabeth Dum and Stephanie Lilja contributed to editing and review. All authors discussed the results and approved the final version of the manuscript.

Competing Interests: There are no conflicts of interest to declare.

Acknowledgments and Funding: The human fibroblasts were kindly provided by Maria Eisenbauer (Institute of Cancer Research, Medical University of Vienna).

\section{REFERENCES}

1. Martin S, Hardy T, Tollefsbol T: Medicinal Chemistry of the Epigenetic Diet and Caloric Restriction. Curr Med Chem 2013, 20:4050-4059.

2. Huffman K: The Developing, Aging Neocortex: How Genetics and Epigenetics Influence Early Developmental Patterning and Age-Related Change. Front Genet 2012, 3.

3. Nishida N, Arizumi T, Takita M, Kitai S, Yada N, Hagiwara $S$, Inoue $T$, Minami $Y$, Ueshima K, Sakurai T, Kudo M: Reactive oxygen species induce epigenetic instability through the formation of 8-hydroxydeoxyguanosine in human hepatocarcinogenesis. Dig Dis 2013, 31(56):459-66.

4. Kwon Y-W, Masutani H, Nakamura H, Ishii Y, Yodoi J: Redox Regulation of Cell Growth and Cell Death. Biol Chem 2003, 384:991-996.

5. Emerit J, Edeas M, Bricaire F: Neurodegenerative diseases and oxidative stress. Biomed Pharmacother 2004, 58:39-46.

6. Mobbs C: Oxidative Stress and Aging. In: Encyclopedia of Stress. Elsevier, 2007: 52-54.

7. Panieri E, Santoro MM: ROS homeostasis and metabolism: a dangerous liason in cancer cells. Cell Death Dis 2016, 7:e2253-e2253.

8. Richter $\mathrm{T}$, Zglinicki $\mathrm{T}$ von: A continuous correlation between oxidative stress and telomere shortening in fibroblasts. Exp Gerontol 2007, 42:1039-1042.
9. Correia-Melo C, Hewitt G, Passos JF: Telomeres, oxidative stress and inflammatory factors: partners in cellular senescence? Longev Heal 2014, 3:1.

10. Fasching $\mathrm{CL}$ : Telomere length measurement as a clinical biomarker of aging and disease. Crit Rev Clin Lab Sci 2018, 55:443-465.

11. Jiang $\mathrm{H}, \mathrm{Ju} \mathrm{Z}$, Rudolph $\mathrm{KL}$ : Telomere shortening and ageing. $Z$ Gerontol Geriatr 2007, 40:314-324.

12. Cawthon RM, Smith KR, O'Brien E, Sivatchenko A, Kerber RA: Association between telomere length in blood and mortality in people aged 60 years or older. Lancet 2003, 361:393-395.

13. Ahmed A, Tollefsbol T: Telomeres, Telomerase, and Telomerase Inhibition: Clinical Implications for Cancer. J Am Geriatr Soc 2003, 51:116-122.

14. Bryce LA, Morrisont N, Hoare SF, Muir S, Keith WN: Mapping of the Gene for the Human Telomerase Reverse Transcriptase, hTERT, to Chromosome 5p15.33 by Fluorescence in Situ Hybridization. Neoplasia 2000, 2:197-201.

15. Monsen RC, Deleeuw L, Dean WL, Gray RD, Sabo TM, Chakravarthy S, Chaires JB, Trent JO: The hTERT core promoter forms three parallel G-quadruplexes. Nucleic Acids Res 2020, 48:5720-5734.

16. Varshney D, Spiegel J, Zyner K, Tannahill D, Balasubramanian $\mathrm{S}$ : The regulation and functions of DNA and RNA G-quadruplexes. Nat Rev Mol Cell Biol 2020, 21:459-474.

17. Ruden $\mathrm{M}$, Puri $\mathrm{N}$ : Novel anticancer therapeutics targeting telomerase. Cancer Treat Rev 2013, 39:444456.

18. Fang $M Z$, Wang $Y, A i N$, Hou Z, Sun $Y$, Lu H, Welsh $W$, Yang CS: Tea Polyphenol (-)-Epigallocatechin-3-Gallate Inhibits DNA Methyltransferase and Reactivates Methylation-Silenced Genes in Cancer Cell Lines. Cancer Res 2003, 63:7563-7570.

19. Li W, Li $Q$, Tan Z: Epigallocatechin gallate induces telomere fragmentation in HeLa and 293 but not in MRC- 5 cells. Life Sci 2005, 76:1735-1746.

20. Renaud S: CTCF binds the proximal exonic region of hTERT and inhibits its transcription. Nucleic Acids Res 2005, 33:6850-6860.

21. Gong Z, Zhu J-K: Active DNA demethylation by oxidation and repair. Cell Res 2011, 21:1649-1651.

22. Tompkins JD, Hall C, Chen VC -y., Li AX, Wu X, Hsu D, Couture L a, Riggs AD: Epigenetic stability, adaptability, and reversibility in human embryonic stem cells. Proc Natl Acad Sci 2012, 109:12544-12549.

23. González-Vallinas M, González-Castejón M, RodríguezCasado A, Ramírez de Molina A: Dietary phytochemicals in cancer prevention and therapy: a complementary approach with promising perspectives. Nutr Rev 2013, 71:585-599.

24. Sheng R, Gu Z-L, Xie M-L: Epigallocatechin gallate, the major component of polyphenols in green tea, inhibits telomere attrition mediated cardiomyocyte apoptosis in cardiac hypertrophy. Int J Cardiol 2013, 162:199-209. 
25. Makpol S, Durani LW, Chua KH, Mohd Yusof YA, Wan Ngah WZ: Tocotrienol-Rich Fraction Prevents Cell Cycle Arrest and Elongates Telomere Length in Senescent Human Diploid Fibroblasts. J Biomed Biotechnol 2011, 2011:1-11.

26. Daniel M, Tollefsbol TO: Epigenetic linkage of aging, cancer and nutrition. J Exp Biol 2015, 218:59-70.

27. Pandey KB, Rizvi SI: Plant Polyphenols as Dietary Antioxidants in Human Health and Disease. Oxid Med Cell Longev 2009, 2:270-278.

28. Rajendran $\mathrm{P}, \mathrm{Ho}$ E, Williams DE, Dashwood RH: Dietary phytochemicals, HDAC inhibition, and DNA damage/repair defects in cancer cells. Clin Epigenetics 2011, 3:4.

29. Mittal A, Pate M, Wylie R, Tollefsbol T, Katiyar S: EGCG down-regulates telomerase in human breast carcinoma MCF-7 cells, leading to suppression of cell viability and induction of apoptosis. Int J Oncol 2004, 24:703-710.

30. Khan N, Afaq F, Saleem M, Ahmad N, Mukhtar H: Targeting Multiple Signaling Pathways by Green Tea Polyphenol (-)-Epigallocatechin-3-Gallate. Cancer Res 2006, 66:2500-2505.

31. Ahmad N, Cheng P, Mukhtar H: Cell Cycle Dysregulation by Green Tea Polyphenol Epigallocatechin-3-Gallate. Biochem Biophys Res Commun 2000, 275:328-334.

32. Liberto $M$, Cobrinik D: Growth factor-dependent induction of p21CIP1 by the green tea polyphenol, epigallocatechin gallate. Cancer Lett 2000, 154:151161.

33. Wu D, Liu Z, Li J, Zhang Q, Zhong P, Teng T, Chen M, Xie Z, Ji A, Li Y: Epigallocatechin-3-gallate inhibits the growth and increases the apoptosis of human thyroid carcinoma cells through suppression of EGFR/RAS/RAF/MEK/ERK signaling pathway. Cancer Cell Int 2019, 19:43.

34. Zappe K, Pointner A, Switzeny OJ, Magnet U, Tomeva E, Heller J, Mare G, Wagner K-H, Knasmueller S, Haslberger AG: Counteraction of Oxidative Stress by Vitamin $E$ Affects Epigenetic Regulation by Increasing Global Methylation and Gene Expression of MLH1 and DNMT1 Dose Dependently in Caco-2 Cells. Oxid Med Cell Longev 2018, 2018:1-13.

35. O'Callaghan NJ, Fenech M: A quantitative PCR method for measuring absolute telomere length. Biol Proced Online 2011, 13:3.

36. Lin J, Smith DL, Esteves K, Drury S: Telomere length measurement by qPCR - Summary of critical factors and recommendations for assay design. Psychoneuroendocrinology 2019, 99:271-278.

37. Hou M, Xu D, Björkholm M, Gruber A: Real-time quantitative telomeric repeat amplification protocol assay for the detection of telomerase activity. Clin Chem 2001, 47:519-524.

38. Rahat B, Hamid A, Ahmad Najar R, Bagga R, Kaur J: Epigenetic mechanisms regulate placental c-myc and hTERT in normal and pathological pregnancies; c-myc as a novel fetal DNA epigenetic marker for pre-eclampsia.
Mol Hum Reprod 2014, 20:1026-1040.

39. Switzeny OJ, Christmann M, Renovanz M, Giese A, Sommer C, Kaina B: MGMT promoter methylation determined by HRM in comparison to MSP and pyrosequencing for predicting high-grade glioma response. Clin Epigenetics 2016, 8:49.

40. Günes C, Rudolph KL: The Role of Telomeres in Stem Cells and Cancer. Cell 2013, 152:390-393.

41. Hapangama DK, Turner MA, Drury JA, Quenby S, Saretzki G, Martin-Ruiz C, Von Zglinicki T: Endometriosis is associated with aberrant endometrial expression of telomerase and increased telomere length. Hum Reprod 2008, 23:1511-1519.

42. Kuhnert N, Dairpoosh F, Jaiswal R, Matei M, Deshpande S, Golon A, Nour H, Karaköse H, Hourani N: Hill coefficients of dietary polyphenolic enzyme inhibitiors: can beneficial health effects of dietary polyphenols be explained by allosteric enzyme denaturing? J Chem Biol 2011, 4:109-116.

43. Kwak TW, Park S-B, Kim H-J, Jeong Y-I, Kang DH: Anticancer activities of epigallocatechin-3-gallate against cholangiocarcinoma cells. Onco Targets Ther 2016, Volume 10:137-144.

44. Singh BN, Shankar S, Srivastava RK: Green tea catechin, epigallocatechin-3-gallate (EGCG): Mechanisms, perspectives and clinical applications. Biochem Pharmacol 2011, 82:1807-1821.

45. Negri A, Naponelli V, Rizzi F, Bettuzzi S: Molecular Targets of Epigallocatechin-Gallate (EGCG): A Special Focus on Signal Transduction and Cancer. Nutrients 2018, 10:1936.

46. Sommer A, Royle NJ: ALT: A multi-faceted phenomenon. Genes 2020

47. McNally EJ, Luncsford PJ, Armanios M: Long telomeres and cancer risk: The price of cellular immortality. J Clin Invest 2019,

48. Gong Y, Stock AJ, Liu Y: The enigma of excessively long telomeres in cancer: lessons learned from rare human POT1 variants. Curr Opin Genet Dev 2020, 60:48-55.

49. De Vitis $M$, Berardinelli $F$, Sgura A: Telomere Length Maintenance in Cancer: At the Crossroad between Telomerase and Alternative Lengthening of Telomeres (ALT). Int J Mol Sci 2018, 19:606.

50. Castelo-Branco P, Choufani S, Mack S, Gallagher D, Zhang C, Lipman T, Zhukova N, Walker EJ, Martin D, Merino D, Wasserman JD, Elizabeth C, Alon N, Zhang L, Hovestadt V, Kool M, Jones DTW, Zadeh G, Croul S, Hawkins C, Hitzler J, Wang JCY, Baruchel S, Dirks PB, Malkin D, Pfister S, Taylor MD, Weksberg R, Tabori U: Methylation of the TERT promoter and risk stratification of childhood brain tumours: An integrative genomic and molecular study. Lancet Oncol 2013, 14:534-542.

51. Lewis KA, Tollefsbol TO: Regulation of the Telomerase Reverse Transcriptase Subunit through Epigenetic Mechanisms. Front Genet 2016, 7:83.

52. Berletch JB, Liu C, Love WK, Andrews LG, Katiyar SK, Tollefsbol TO: Epigenetic and genetic mechanisms 
contribute to telomerase inhibition by EGCG. J Cell Biochem 2008, 103:509-519.

53. Bollati V, Schwartz J, Wright R, Litonjua A, Tarantini L, Suh $H$, Sparrow D, Vokonas $P$, Baccarelli A: Decline in genomic DNA methylation through aging in a cohort of elderly subjects. Mech Ageing Dev 2009, 130:234-239.

54. Horvath S: DNA methylation age of human tissues and cell types. Genome Biol 2013, 14:R115.

55. Florath I, Butterbach K, Muller H, Bewerunge-Hudler M, Brenner $\mathrm{H}$ : Cross-sectional and longitudinal changes in DNA methylation with age: an epigenome-wide analysis revealing over 60 novel age-associated $\mathrm{CpG}$ sites. Hum Mol Genet 2014, 23:1186-1201.

56. Guilleret I, Benhattar J: Unusual distribution of DNA methylation within the hTERT CpG island in tissues and cell lines. Biochem Biophys Res Commun 2004, 325:1037-1043.

57. Garg P, Joshi RS, Watson C, Sharp AJ: A survey of interindividual variation in DNA methylation identifies environmentally responsive co-regulated networks of epigenetic variation in the human genome. PLOS Genet 2018, 14:e1007707.

58. Barrera LN, Johnson IT, Bao Y, Cassidy A, Belshaw NJ: Colorectal cancer cells Caco-2 and HCT116 resist epigenetic effects of isothiocyanates and selenium in vitro. Eur J Nutr 2013, 52:1327-1341.

59. Miller DM, Thomas SD, Islam A, Muench D, Sedoris K: CMyc and Cancer Metabolism. Clin Cancer Res 2012, 18:5546-5553.

60. Gabay M, Li Y, Felsher DW: MYC Activation Is a Hallmark of Cancer Initiation and Maintenance. Cold Spring Harb Perspect Med 2014, 4:a014241-a014241.

61. Dang C V.: MYC on the Path to Cancer. Cell 2012, 149:22-35

62. Wang $M$, Lei $Y X$ : Effects of tea polyphenols on proliferation and apoptosis of cadmium-transformed cells. Int J Clin Exp Med 2015, 8:3054-3062.

63. Ahmed W, Lingner J: PRDX1 and MTH1 cooperate to prevent ROS-mediated inhibition of telomerase. Genes Dev 2018, 32:658-669.

64. Udroiu I, Marinaccio J, Sgura A: Epigallocatechin-3gallate induces telomere shortening and clastogenic damage in glioblastoma cells. Environ Mol Mutagen 2019, 60:683-692.

65. Kim H-S, Quon MJ, Kim J: New insights into the mechanisms of polyphenols beyond antioxidant properties; lessons from the green tea polyphenol, epigallocatechin 3-gallate. Redox Biol 2014, 2:187-195.

66. Zhou D-H, Wang X, Yang M, Shi X, Huang W, Feng Q: Combination of Low Concentration of (-) Epigallocatechin Gallate (EGCG) and Curcumin Strongly Suppresses the Growth of Non-Small Cell Lung Cancer in Vitro and in Vivo through Causing Cell Cycle Arrest. Int J Mol Sci 2013, 14:12023-12036.

67. Noguchi M, Yokoyama M, Watanabe S, Uchiyama M, Nakao Y, Hara K, Iwasaka T: Inhibitory effect of the tea polyphenol, (-)-epigallocatechin gallate, on growth of cervical adenocarcinoma cell lines. Cancer Lett 2006, 234:135-142.

68. Ran Z-H: Apoptotic effect of Epigallocatechin-3-gallate on the human gastric cancer cell line MKN45 via activation of the mitochondrial pathway. World J Gastroenterol 2007, 13:4255.

69. Luo K-W, Lung W-Y, Chun-Xie, Luo X-L, Huang W-R: EGCG inhibited bladder cancer T24 and 5637 cell proliferation and migration via PI3K/AKT pathway. Oncotarget 2018, 9:12261-12272.

70. Sugisawa A, Umegaki K: Physiological Concentrations of (-)-Epigallocatechin-3-O-Gallate (EGCg) Prevent Chromosomal Damage Induced by Reactive Oxygen Species in WIL2-NS Cells. J Nutr 2002, 132:1836-1839.

71. Roychoudhury S, Agarwal A, Virk G, Cho C-L: Potential role of green tea catechins in the management of oxidative stress-associated infertility. Reprod Biomed Online 2017, 34:487-498.

72. Zhu Z-Z, Hou L, Bollati V, Tarantini L, Marinelli B, Cantone L, Yang AS, Vokonas $\mathrm{P}$, Lissowska J, Fustinoni $\mathrm{S}$, Pesatori AC, Bonzini M, Apostoli P, Costa G, Bertazzi PA, Chow W-H, Schwartz J, Baccarelli A: Predictors of global methylation levels in blood DNA of healthy subjects: a combined analysis. Int J Epidemiol 2012, 41:126-139.

73. Wang C-T, Chang H-H, Hsiao C-H, Lee M-J, Ku H-C, Hu YJ, Kao Y-H: The effects of green tea (-)-epigallocatechin3-gallate on reactive oxygen species in 3T3-L1 preadipocytes and adipocytes depend on the glutathione and $67 \mathrm{kDa}$ laminin receptor pathways. Mol Nutr Food Res 2009, 53:349-360.

74. Esmaeelpanah E, Razavi BM, Vahdati Hasani F, Hosseinzadeh $\mathrm{H}$ : Evaluation of epigallocatechin gallate and epicatechin gallate effects on acrylamide-induced neurotoxicity in rats and cytotoxicity in PC 12 cells. Drug Chem Toxicol 2018, 41:441-448.

75. Lambert JD, Kennett MJ, Sang S, Reuhl KR, Ju J, Yang CS: Hepatotoxicity of high oral dose (-)-epigallocatechin-3gallate in mice. Food Chem Toxicol 2010, 48:409-416.

76. Chung JE, Tan S, Gao SJ, Yongvongsoontorn N, Kim SH, Lee JH, Choi HS, Yano H, Zhuo L, Kurisawa M, Ying JY: Self-assembled micellar nanocomplexes comprising green tea catechin derivatives and protein drugs for cancer therapy. Nat Nanotechnol 2014, 9:907-912.

77. Sanna V, Singh CK, Jashari R, Adhami VM, Chamcheu JC, Rady I, Sechi M, Mukhtar H, Siddiqui IA: Targeted nanoparticles encapsulating (-)-epigallocatechin-3gallate for prostate cancer prevention and therapy. Sci Rep 2017, 7:41573.

78. Yamamoto T, Hsu S, Lewis J, Wataha J, Dickinson D, Singh B, Bollag WB, Lockwood P, Ueta E, Osaki T, Schuster G: Green Tea Polyphenol Causes Differential Oxidative Environments in Tumor versus Normal Epithelial Cells. J Pharmacol Exp Ther 2003, 307:230236.

79. Elbling L, Weiss R-M, Teufelhofer $\mathrm{O}$, Uhl M, Knasmueller S, Schulte-Hermann R, Berger W, Micksche M: Green tea extract and (-)-epigallocatechin-3-gallate, the major tea catechin, exert oxidant but lack antioxidant activities. FASEB J 2005, 19:807-809. 
80. Kwon SJ, Lambert JD, Yang CS, Hong J: Role of reactive oxygen species from the green tea catechin, (-)epigallocatechin-3-gallate in growth modulation of intestinal cells. Food Sci Biotechnol 2015, 24:15411548.

81. Naasani I, Oh-hashi F, Oh-hara T, Feng WY, Johnston J, Chan K, Tsuruo T: Blocking telomerase by dietary polyphenols is a major mechanism for limiting the growth of human cancer cells in vitro and in vivo. Cancer Res 2003, 63:824-830.

82. Koonyosying $\mathrm{P}$, Kongkarnka $\mathrm{S}$, Uthaipibull C, Svasti $\mathrm{S}$, Fucharoen S, Srichairatanakool S: Green tea extract modulates oxidative tissue injury in beta-thalassemic mice by chelation of redox iron and inhibition of lipid peroxidation. Biomed Pharmacother 2018, 108:16941702

83. Khademi F, Totonchi $\mathrm{H}$, Mohammadi N, Zare R, Zal F: Nicotine-Induced Oxidative Stress in Human Primary Endometrial Cells. Int J Toxicol 2019, 38:202-208.

84. Al-Basher Gl: Green tea activity and iron overload induced molecular fibrogenesis of rat liver. Saudi J Biol Sci 2019, 26:531-540.

85. Lambert JD, Elias RJ: The antioxidant and pro-oxidant activities of green tea polyphenols: A role in cancer prevention. Arch Biochem Biophys 2010, 501:65-72.

86. Feng $B$, Fang $Y$, Wei SM: Effect and mechanism of epigallocatechin-3-gallate (EGCG). against the hydrogen peroxide-induced oxidative damage in human dermal fibroblasts. J Cosmet Sci 2013, 64:35-44.

87. Rahnasto-Rilla $M$, Tyni J, Huovinen $M$, Jarho $E$, Kulikowicz T, Ravichandran S, A. Bohr V, Ferrucci L, Lahtela-Kakkonen M, Moaddel R: Natural polyphenols as sirtuin 6 modulators. Sci Rep 2018, 8:4163.

88. Amano H, Sahin E: Telomeres and sirtuins: at the end we meet again. Mol Cell Oncol 2019, 6:e1632613.

89. Singh CK, Chhabra G, Ndiaye MA, Garcia-Peterson LM, Mack NJ, Ahmad N: The Role of Sirtuins in Antioxidant and Redox Signaling. Antioxid Redox Signal 2018, 28:643-661.

90. Alhazzazi TY, Kamarajan P, Verdin E, Kapila YL: Sirtuin-3 (SIRT3) and the Hallmarks of Cancer. Genes Cancer 2013, 4:164-171.

91. Narala SR, Allsopp RC, Wells TB, Zhang G, Prasad P, Coussens MJ, Rossi DJ, Weissman IL, Vaziri H: SIRT1 acts as a nutrient-sensitive growth suppressor and its loss is associated with increased AMPK and telomerase activity. Mol Biol Cell 2008,.

92. Amano $\mathrm{H}$, Chaudhury A, Rodriguez-Aguayo $\mathrm{C}$, Lu L, Akhanov V, Catic A, Popov Y V., Verdin E, Johnson H, Stossi F, Sinclair DA, Nakamaru-Ogiso E, Lopez-Berestein G, Chang JT, Neilson JR, Meeker A, Finegold M, Baur JA,
Sahin E: Telomere Dysfunction Induces Sirtuin Repression that Drives Telomere-Dependent Disease. Cell Metab 2019, 29:1274-1290.e9.

93. Zhang B, Chen J, Cheng ASL, Ko BCB: Depletion of Sirtuin 1 (SIRT1) Leads to Epigenetic Modifications of Telomerase (TERT) Gene in Hepatocellular Carcinoma Cells. PLoS One 2014, 9:e84931.

94. Mao B, Zhao G, Lv X, Chen H-Z, Xue Z, Yang B, Liu D-P, Liang C-C: Sirt1 deacetylates C-Myc and promotes CMyc/Max association. Int J Biochem Cell Biol 2011, 43:1573-1581.

95. Jayasena T, Poljak A, Smythe G, Braidy N, Münch G, Sachdev $P$ : The role of polyphenols in the modulation of sirtuins and other pathways involved in Alzheimer's disease. Ageing Res Rev 2013, 12:867-883.

96. Lilja S, Oldenburg J, Pointner A, Dewald L, Lerch M, Hippe B, Switzeny O, Haslberger A: Epigallocatechin Gallate Effectively Affects Senescence and Anti-SASP via SIRT3 in 3T3-L1 Preadipocytes in Comparison with Other Bioactive Substances. Oxid Med Cell Longev 2020, 2020:1-13.

97. Farooqi A, Mansoor $Q$, Alaaeddine N, Xu B: MicroRNA Regulation of Telomerase Reverse Transcriptase (TERT): Micro Machines Pull Strings of Papier-Mâché Puppets. Int J Mol Sci 2018, 19:1051.

98. Rasheed Z, Rasheed N, Al-Shaya O: Epigallocatechin-3O-gallate modulates global microRNA expression in interleukin-1 $\beta$-stimulated human osteoarthritis chondrocytes: potential role of EGCG on negative coregulation of microRNA-140-3p and ADAMTS5. Eur J Nutr 2018, 57:917-928.

99. Varghese E, Liskova A, Kubatka P, Samuel SM, Büsselberg D: Anti-angiogenic effects of phytochemicals on miRNA regulating breast cancer progression. Biomolecules 2020.

100. Fujiki $H$, Sueoka $E$, Watanabe $T$, Suganuma $M$ : Synergistic enhancement of anticancer effects on numerous human cancer cell lines treated with the combination of EGCG, other green tea catechins, and anticancer compounds. J Cancer Res Clin Oncol 2015, 141:1511-1522.

101. Elbling L, Herbacek I, Weiss R-M, Jantschitsch C, Micksche M, Gerner C, Pangratz H, Grusch M, Knasmüller $\mathrm{S}$, Berger W: Hydrogen peroxide mediates EGCG-induced antioxidant protection in human keratinocytes. Free Radic Biol Med 2010, 49:14441452.

102. Tao L, Forester SC, Lambert JD: The role of the mitochondrial oxidative stress in the cytotoxic effects of the green tea catechin, (-)-epigallocatechin-3-gallate, in oral cells. Mol Nutr Food Res 2014, 58:665-676. 